\title{
Weed Destruction by Chemicals
}

$A^{\text {MONGST the many burdens which beset the }}$ A farmer may be included the spread of weeds, owing mainly to the high cost of keeping the land clean by hand in relation to the value of the crop. It is therefore of wide interest that a new method of weed destruction by spraying with sulphuric acid is under trial on a considerable scale, which promises a cheap remedy for the evil, at all events so far as such plants as charlock (Brassica sinapis) and a few other prevalent weeds are concerned. In the past, sulphates of copper and of iron have been used for this purpose with effect, but the ideal conditions for their use, namely, twenty-four hours of fine weather following a humid day for the application, were too difficult to realise in practice. When using sulphuric acid, only an hour or so of dry weather at the time of spraying is essential.

Spraying with sulphuric acid originated in

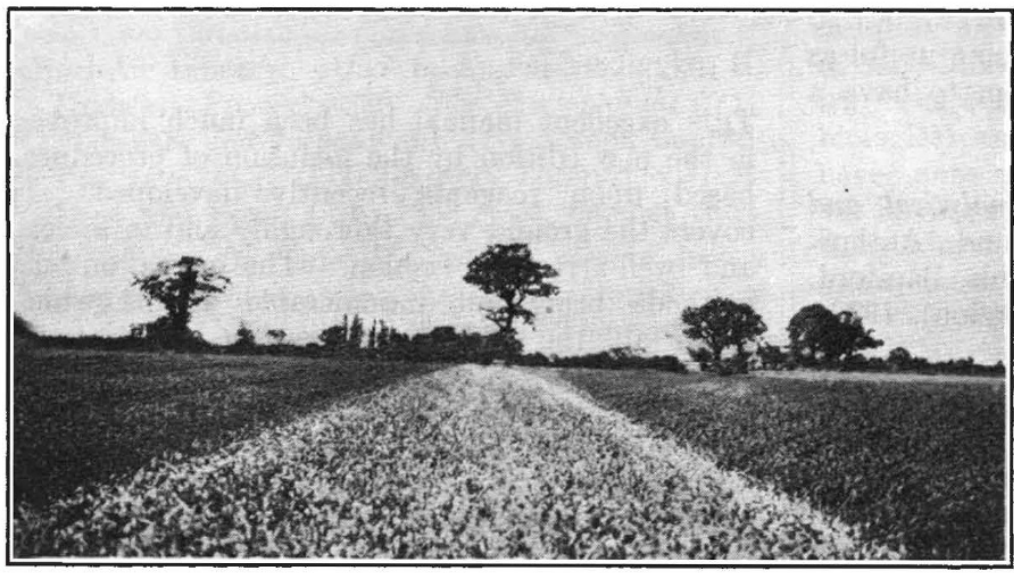

FIG. 1. Field at Doggets Farm, Rochford, one stitch not sprayed. Sprayed A pril 19, photographed June 2.

France, being largely due to the pioneer work of Rabaté, begun in 1911, and it has developed so rapidly that at present several hundred thousand acres are treated annually, involving in 1931 the use of 27,000 tons of acid, whilst some twenty French manufacturers produce suitable spraying machines for its application.

The work in England has been fostered by the National Sulphuric Acid Association with the cooperation of the School of Rural Economy in the University of Oxford, and it has now reached a stage when it has been handed over to the acidmaking industry for practical development. This summer several thousand acres have been sprayed with uniform success and the farming fraternity has evidenced a considerable interest in the novel process.

The method of application is a simple one; commercial brown oil of vitriol is mixed with water to give a solution varying from 7 to 10 per cent in strength, which is sprayed over the land from a suitable machine, either horse- or motordrawn, with acid-resisting parts. It is preferable for the spraying to be done by contract and thus with men used to handling acid, the farmer supplying the necessary traction. About 100 gallons per acre is the normal amount to spray, but the quantity depends upon the size of the charlock and it is increased up to 150 gallons per acre when advisable.

The time of spraying depends on the size of the plant and not on the actual time of year. The most favourable moment is when the charlock is in its four-leaf stage, all the seeds having well germinated, but it is effective even when the charlock is several inches high. In a normal year some five to six weeks are available for spraying, so that a contractor can organise his operations so as to keep his machines occupied by moving them from early to late growing regions.

The object of the spray is to kill the charlock, which may turn completely brown within twenty minutes of its application, without harming the cereals. The spray is not selective in its action, which is due entirely to the difference in the physiology and morphology of the two plants. The outer skin of the cereal is thick and not easily penetrated by the acid, which slips off the smooth vertical leaves, except at the tips of the leaves which turn brown, whilst the tender growing point is protected by the leaves wrapping round it. The skin of the charlock is easily penetrated as the acid adheres to the open, broad, hairy and more or less horizontal leaves, and the tender growing point is exposed so that the tissues are plasmolysed by the acid and eventually destroyed. In sunshine the action takes place so quickly that within an hour of spraying, the whole field turns brown, a quite alarming sight: in a few days the cereal recovers and it soon presents the healthy and luxuriant appearance which normally follows a top dressing of a nitrogenous fertiliser. Fig. 1, showing a field in which, for the purpose of demonstration, a strip has not been treated, brings out very clearly the effect of spraying, so that no further words are required here as to its efficiency.

The cost of spraying is of the order of $12 \mathrm{~s}$. $6 \mathrm{~d}$.15s. per acre, depending on the acreage treated on any one farm: it will be even less when a contractor is fully occupied in a particular district, as much of the cost is occasioned by the transport of the machine. Some 30 per cent of the cost is due to the sulphuric acid, the carriage of which is also costly. The actual benefits of spraying in the way 
of increased crop have not yet been fully established: they are claimed to amount in value to so much as $£ 2-£ 3$ per acre in the most favourable cases. The weeds themselves remove nutrient matter from the soil and they crowd the cereal plant, reducing the crop; when killed by acid, their organic matter is returned to the soil, whilst it is probable that the acid itself may have some effect in increasing soil fertility by accelerating nitrification, though there is no positive evidence on this point.

There is both the immediate gain of an increase in crop and also a reduction of weeds which renders future cultivation more easy : it is stated that, on the Continent, spraying for three or four seasons in succession has resulted in periods of definite freedom from weeds.

The high labour costs of farming, which are bound to persist in Great Britain even when mechanical appliances are more largely adopted, can only be countered by an increased yield of the crop. The production of cheap fertilisers has enabled the requirements of the plant in nitrogen and minerals to be satisfied up to the economic point and interest has been transferred to methods of cultivation, in particular the preparation of the soil and subsoil, as most likely to increase further yields. The ill-effect of weeds has assumed an important aspect and their prevention becomes imperative. Until now this has been largely a question of cultivation and it is still the case with the grasses among cereals, but the discovery that a chemical treatment may eliminate charlock and its like, which have been known to lower a crop of oats by one-third, is a definite step forward, particularly at a time when the wheat quota is once more encouraging the British farmer to produce wheat of good millable quality.

The control of weeds in the garden is not subject to the same economic requirements as on the farm, with the consequence that the use of chemicals for this purpose has been widespread. The old favourites, the poisonous arsenicals, have obvious disadvantages, and the alternative tar products have the drawback of being caustic. It is of interest, therefore, to note the success which is attending the use of ten per cent solutions, applied at the rate of one gallon to twelve square yards, of the chlorates of sodium and calcium, which appear to be particularly deadly to weeds and grass.

The foregoing at least provides evidence that chemical science is finding new ways of proving its utility to agriculture and horticulture.

\section{Annual Meeting of the Royal Society of Canada}

rTHE Royal Society of Canada held its annual meeting on May 18-20, at Queen's University, Kingston.

The president, Prof. Francis E. Lloyd, Macdonald professor of botany in McGill University, delivered his address on the evening of May 18. His subject was "The Carnivorous Plants" and it included not only an interesting review of the principal types, illustrated by beautiful slides and motion pictures, but also many original contributions regarding the structure and function of their traps. At the same meeting, the Flavelle medal was presented to Dr. J. B. Tyrrell for his great contributions to the geography and geology of Canada, and the Tyrrel medal to Judge F. W. Howay in recognition of his literary and historical work.

The Society passed a resolution urging the Government to give liberal support to the National Research Council of Canada in virtue of the results which it has achieved and of the still greater benefits which, if supported, it will in the future bring to the country.

At the meetings of Section 1 (French Literature, History, etc.) nineteen papers, and of Section 2 (English Literature, History, etc.) twenty-six papers were presented.

In his presidential address to Section 3 (Mathematical, Chemical and Physical Sciences), Prof. C. A. Chant dealt with the inception and constructional progress of the new 74-in. telescope at the University of Toronto. After paying tribute to the generosity of the donor, Mrs. David Dunlop,
Prof. Chant told how the project is being carried out. The administration building is nearly completed and the great dome will be erected during the summer. The mirror is to be made of pyrex glass of especially low expansion coefficient, which is expected to be of great advantage. Delivery for grinding is promised by the makers in September.

The programms of papers was very crowded, one hundred and forty-three papers being presented. Consequently, only a few typical papers can be mentioned even briefly here.

There was a number of papers on geophysical prospecting by Prof. W. L. Miller and by Prof. L. Gilchrist and his co-workers, using gravitational, electrical and magnetic methods. A portable Geiger counter has been developed by Shrum for detecting radioactive ores. Several papers dealing with hyperfine structure and other spectroscopic problems by M. F. Crawford, Mackay and others of the Toronto school were presented by Prof. E. F. Burton. An interesting application of polar front methods has been made by Thomson to a typical Canadian winter weather situation. An oscillographic study of reflection of wireless waves from the Kennelly-Heaviside and Appleton layers by Ross has yielded valuable information, particularly regarding multiple reflections (up to tenfold). A report on Canadian radio experiments during the 1932 eclipse was presented by Rose. The results taken as a whole are strongly against the idea of a corpuscular eclipse.

In mathematics and astronomy, Prof. C. F. 